\title{
De anatomie van de eed
}

Citation for published version (APA):

van Overbeeke, K. (2009). De anatomie van de eed. Maastricht University. https://doi.org/10.26481/spe.20091107ko

Document status and date:

Published: 07/11/2009

DOI:

10.26481/spe.20091107ko

Document Version:

Publisher's PDF, also known as Version of record

\section{Please check the document version of this publication:}

- A submitted manuscript is the version of the article upon submission and before peer-review. There can be important differences between the submitted version and the official published version of record.

People interested in the research are advised to contact the author for the final version of the publication, or visit the DOI to the publisher's website.

- The final author version and the galley proof are versions of the publication after peer review.

- The final published version features the final layout of the paper including the volume, issue and page numbers.

Link to publication

\footnotetext{
General rights rights.

- You may freely distribute the URL identifying the publication in the public portal. please follow below link for the End User Agreement:

www.umlib.nl/taverne-license

Take down policy

If you believe that this document breaches copyright please contact us at:

repository@maastrichtuniversity.nl

providing details and we will investigate your claim.
}

Copyright and moral rights for the publications made accessible in the public portal are retained by the authors and/or other copyright owners and it is a condition of accessing publications that users recognise and abide by the legal requirements associated with these

- Users may download and print one copy of any publication from the public portal for the purpose of private study or research.

- You may not further distribute the material or use it for any profit-making activity or commercial gain

If the publication is distributed under the terms of Article $25 \mathrm{fa}$ of the Dutch Copyright Act, indicated by the "Taverne" license above, 
De anatomie van de eed 


\section{Colofon}

Ontwerp en print: Océ Business Services, Maastricht

ISBN: 9789056813079

NUR: 877

Alle rechten voorbehouden. Niets uit deze uitgave mag worden verveelvoudigd, opgeslagen in een geautomatiseerd gegevensbestand of openbaar gemaakt worden, zonder voorafgaande schriftelijke toestemming van de auteur of uitgever. 


\section{De anatomie van de eed}

Faculty of Health, Medicine and Life Sciences

at Maastricht University

Maastricht, 7 november 2009

Prof. dr. Koo van Overbeeke 
De anatomie van de eed 
Dames en Heren,

In maart 1973 kreeg ik het bericht dat ik Geneeskunde aan de rijksuniversiteit van Utrecht mocht gaan studeren. Ik had echter een probleem: ik vervulde toen mijn dienstplicht in het Nederlandse leger. Na wat ongewenste vertragingen op de middelbare school vond mijn vader het beter dat ik eerst de dienstplicht zou gaan vervullen. Ik zou dan wellicht wat meer studie motivatie krijgen, dat was gedurende mijn middelbare school periode nogal een probleem geweest. Ik zou pas in januari 1974 afzwaaien en kon dus niet in september 1973 met mijn studie beginnen. In de veronderstelling dat ik een positief antwoord zou krijgen, vroeg ik aan de pelotonscommandant of ik eerder het leger mocht verlaten omdat ik voor dokter kon gaan studeren. Dit zou toch een betere tijdsbesteding kunnen zijn dan mijn dienstplicht. Tot mijn teleurstelling kreeg ik te horen dat dat niet kon, ik had een dure rijopleiding in het leger gehad en dat moest ten volle worden benut. Ik liet het daarbij niet zitten en bewandelde alle wegen die er waren om toch maar eerder het leger te kunnen verlaten. Pas toen besefte ik dat ik ontzettend graag dokter wilde worden, dat besef gaf mij een warm gevoel, een gevoel dat ik nu, 35 jaar later, nog steeds heb. Ik kreeg eindelijk echt zin om te gaan studeren.

Plotseling zonder enige reden mocht ik eind september 1973 het leger verlaten; kennelijk was er niets meer over om eer aan mij te behalen.

Dan begon het eerste jaar met onderwijs in de zoölogie, fysiologie, klinische chemie, histologie en klinische genetica en langzaam maar zeker zakte de motivatie voor het artsen vak in mijn schoenen. Echter het onderwijs in de anatomie hield mij overeind. De kennis en de eigen dissecties van het anatomisch menselijk materiaal op de snijzaal en de kennis van de prachtige samenhang van de menselijke anatomisch structuren bleef voor mij, en voor vele medestudenten, de basis om gemotiveerd te blijven en de minder motiverende vakken voor lief te nemen. Alleen de anatomie laat de verbanden waruit het menselijk lichaam bestaat zien en verklaart de pathofysiologie in de kliniek. Het is jammer en misschien ook wel kortzichtig dat het anatomie onderwijs met de daarbijbehorende snijzaal practica waarbij de student zelf de vaardigheid van de anatomische dissecties aanleert om reden van bezuiniging is veranderd in aanschouwelijk onderwijs aan de hand van digitale beelden en voorgeprepareerde preparaten. Voor bijna elke arts is de anatomie de basis van het klinisch denken, voor de snijdend specialist is de anatomie de basis voor zijn keuze voor het snijdend vak. 
Mijn liefde en belangstelling voor de anatomie heeft geleid tot een promotie en publicaties en voordrachten over de anatomie van de cirkel van Willis ( een vaatstructuur nabij de schedelbasis) en anatomisch onderzoek van de schedelbasis met de daarbij behorende chirurgische benaderingen. Vrijwel elke neurochirurg in Nederland heeft wel eens een voordracht van mij over een anatomisch onderwerp moeten aanhoren. De kennis van de anatomie verandert nooit en blijft actueel. Medische behandelingen en operaties worden vaak geïnspireerd door de waan van de dag en veranderen dientengevolge door de jaren heen, de anatomie waarop deze inzichten zijn gebaseerd blijft zoals die was: Surgery is for the moment, anatomy is forever.

Op 24 juli 1980 legde ik de artsen eed af.

Bij het toetreden tot de beroepsgemeenschap van artsen wordt een belofte afgelegd of wordt een eed gezworen over toewijding, gedrag ten opzichte van de patiënten en ethische opvattingen van de medicus. De eed heeft geen juridische status; er is geen wettelijke verplichting en daarom heeft het al dan niet uitspreken van de eed geen consequenties voor de inschrijving als arts in het BIG register of voor de uitoefening van het vak als arts. Indien dat wel het geval was zouden artsen die toezicht houden bij een bokswedstrijd en sommige zogenaamde cosmetische chirurgen van meineed kunnen worden beschuldigd.

Het uitspreken van de eed is nog steeds een traditie aan alle Nederlandse universiteiten en ik zie het nog steeds als een openbare bekrachtiging van een waardige beoefening van het beroep van arts.

De eed is gebaseerd op de eed van Hippocrates die ca. 400 jaar voor de geboorte van Christus leefde. Een tijdgenoot van Hippocrates was Socrates, die beschouwd wordt als de grondlegger van de ethiek. Volgens Socrates moest je een leven leiden die je ziel waardig is. Daarvoor moest je kennis opdoen en koppelen aan het goede ofwel aan de deugd. Daarvoor moet men eerst het goede leren kennen. Volgens Socrates is het onmogelijk het goede te doen zonder het te kennen zoals het ook onmogelijk is het goede niet te doen als men het goede eenmaal kent. We vinden deze Socratische denkwijze terug in de eed van Hippocrates. De eed van Hippocrates bevat dat de medische kennis van de arts wordt onderwezen en wordt geleerd en vervolgens ten dienste wordt gesteld aan de ethiek en moraal en aan zijn medemens als onderdeel van zijn deugd. Wellicht gaat Hippocrates iets te ver. Hij laat zijn leerling bijvoorbeeld het volgende beloven: 
- ik zal hem, die mij de geneeskunst heeft onderwezen, beschouwen als een vader, en hem laten delen in mijn levensonderhoud, en als hij in schulden of nood zou geraken, hem op zijn verzoek steun verlenen-

Aldus Hippocrates. Was dat maar waar want ik ben al 10 jaar opleider in de neurochirurgie. Ik denk dat mijn assistenten dit echt niet beloven, zeker niet nu we met een krediet crisis te maken hebben.

Toch blijft de essentie van de eed van Hippocrates al meer dan twee millennia actueel en een waardevol instrument dat artsen in al hun verscheidenheid bijlicht. Dit is vergelijkbaar met de anatomie: de maatschappij verandert, de geneeskunde krijgt nieuwe en andere inzichten, echter de verantwoordelijkheid van de opleider voor zijn leerlingen en de verantwoordelijkheid van de arts voor zijn patiënten is en blijft hetzelfde.

\section{Hoe luidt de eed van Hippocrates? Ik citeer de meest actuele versie}

Ik zweer/beloof dat ik de geneeskunst zo goed als ik kan zal uitoefenen ten dienste van mijn medemens. Ik zal zorgen voor zieken, gezondheid bevorderen en lijden verlichten. Ik stel het belang van de patiënt voorop en eerbiedig zijn opvattingen. Ik zal aan de patiënt geen schade doen. Ik luister en zal hem goed inlichten. Ik zal geheim houden wat mij is toevertrouwd. Ik zal de geneeskundige kennis van mijzelf en anderen bevorderen. Ik erken de grenzen van mijn mogelijkheden. Ik zal mij open en toetsbaar opstellen, en ik ken mijn verantwoordelijkheid voor de samenleving. Ik zal de beschikbaarheid en toegankelijkheid van de gezondheidszorg bevorderen. Ik maak geen misbruik van mijn medische kennis, ook niet onder druk. Ik zal zo het beroep van arts in ere houden."

\section{Staat $u$ mij toe dat ik een paar aspecten van deze eed anatomisch ga ontleden.}

Ik zweer of ik beloof dat ik de geneeskunst zo goed als ik kan zal uitoefenen ten dienste van mijn medemens. Dat is de eerste regel van de eed.

Wat is "zo goed als ik kan"?

De zorgverzekeraar gaat anno 2008 nog verder met deze vraag en zoekt in het kader van de inkoop gerelateerd aan de marktwerking de beste dokter en het beste ziekenhuis voor zijn cliënt. Ook wordt over 
de beste arts en het beste ziekenhuis gesproken in enquêtes van het Algemeen Dagblad en Elsevier. De ziektenkostenverzekeraar CZ gaat nog verder en lokt in een advertentie in de Volkskrant van 2 weken geleden zijn cliënten met het vooruitzicht dat zij op kosten van $C Z$ de beste medische topspecialist in de wereld mogen benaderen voor een second opinion. Deze beste dokter, deze topspecialist geeft dan op basis van het ingestuurde patiënten dossier ( moet wel eerst vertaald worden, denk ik) zonder de patiënt te hebben gezien en zonder de patiënt te hebben onderzocht en zonder met de eerdere behandelaars te hebben gecommuniceerd zijn mening. Volgens CZ wordt in $29 \%$ van die gevallen de eerdere diagnose aangepast en in maar liefst $56 \%$ wordt een afwijkend behandelplan voorgesteld. Logisch, als je alleen maar uit kunt gaan van een patientendossier is de kans dat er een afwijkende mening ontstaat niet onaanzienlijk. Echter deze beste dokter ergens op onze planeet voldoet niet aan de eed van Hippocrates, want alleen een patientendossier bestuderen zonder een patiënt te hebben gezien of een medebehandelaar te hebben gesproken past niet bij de term "zo goed als ik kan". De ziektenkostenverzekeraar trekt zich daar weinig van aan, het verwerven van premiebetalende klanten is belangrijker.

De beste dokter, het beste ziekenhuis. Maar wie is de beste dokter en waar is het beste ziekenhuis? De medische specialist in het academische ziekenhuis, of liever toch de specialist in een topklinisch niet-academisch ziekenhuis of juist de specialist in een relatief kleiner streekziekenhuis. Niet medische zaken zoals parkeergelegenheid, de kwaliteit van de koffie en de stoelen in de wachtkamer en de wachttijden en wachtlijsten kunnen worden gemeten. Maar hoe meten we vertrouwen, betrokkenheid, sympathie, empathie en het nivo van de medische en paramedische kennis? Dit zijn de essentiële onderdelen van het visitekaartje van het ziekenhuis. Mensen vergeten meestal dat ze lang op de specialist hebben moeten wachten, maar onthouden een chagrijnige onvakkundige arts, een onaardige verpleegkundige of een ongeïnteresseerde poli medewerker.

Is de specialist met de meeste ervaring de beste dokter? Het behoeft geen betoog of onderzoek. ledereen weet het uit ervaring. Niets bevordert de geneeskunde meer dan de ervaring. Maar ervaring doet men op uit onervarenheid, er is een learning curve, en veel ervaring leidt tot een onvermijdelijke oppervlakkigheid.

Ik heb tenminste 3000 lumbale hernia operaties gedaan. Het getal 3000 zegt niets over mijn resultaten, hooguit dat ik er veel gedaan heb 
en dus wel ervaring zal hebben. Zoals ik al zei: ervarenheid kan leiden tot oppervlakkigheid. Een groot deel van deze operaties heb ik gedaan samen met een assistent in opleiding tot neurochirurg die dan afhankelijk van de fase van zijn opleiding de operatie zelf of voor een gedeelte zelf deed. Dat maakt mijn ervaring anders. In het kader van de opleiding wordt steeds weer opnieuw de indicatie, het resultaat en eventuele complicaties van de operatie geëvalueerd en eventuele verbeteringen en leermomenten besproken. Een voortdurende zelfreflectie, update van kennis en een kritische evaluatie door leerlingen en mijzelf is dan nodig. Hetzelfde is nodig als men in een team werkt waarin wederzijds respect maar ook een wederzijdse kritische evaluatie van elkaar bestaat. Deze condities dragen mijns inziens meer bij aan het predikaat "de beste arts" dan het aantal verrichte medische handelingen en/of medische publicaties en voordrachten.

De geneeskunst zo goed als mogelijk uitoefenen ten dienste van de medemens kan een arts anno 2008 in de meerderheid der gevallen niet meer alleen.

Met andere woorden de beste arts in het beste ziekenhuis kan eigenlijk niet alleen zijn maar moet met meerdere collega's samenwerken; collega's die voortdurend met elkaar communiceren ook buiten kantooruren en elkaar professioneel respecteren en accepteren.

De hoeveelheid medisch wetenschappelijke informatie dat maandelijks wordt gepubliceerd is ten gevolge van de digitale communicatie zo omvangrijk dat een specialist niet meer in staat is alles tot zich te nemen. Steeds meer is er sprake van discipline overschrijdende informatie zodat de grenzen van elk specialisme zo langzamerhand aan het vervagen zijn. Dat betekent dat de beste dokter zich moet specialiseren binnen zijn discipline om een expert te worden en te blijven. Vervolgens zullen deze topspecialisten zich moeten groeperen in een team van specialisten die allemaal hun eigen professionele inbreng hebben in een bepaalde en beperkte pathologie. Het is bekend dat een team bestaande uit een heterogene samenstelling met vooral ook jongere teamleden beter presteert. Het vormen van multidisciplinaire teams rondom een bepaald ziektebeeld is essentieel voor het predikaat de beste arts. Liever spreek ik dan over het beste team. Een team van artsen en andere medebehandelaars zoals verpleegkundigen en paramedici en medisch opgeleide technici. Afdelingen worden dan niet langer genoemd naar het soort specialisme (zoals de afdeling neurochirurgie) maar afdelingen worden genoemd naar het soort pathologie. Deze afdelingen worden bestuurd door een multidisciplinair team met korte lijnen en een 
natuurlijke onderlinge chemie tussen de leden van het team. Een onderling respect voor kennis en inbreng is essentieel, zo niet de eerste voorwaarde voor een goed functioneren van deze behandelteams. Een academische titel, publicaties, voordrachten, het al dan niet deelnemen of leiden van nationale en internationale studies is van secundair belang. Liever een vakkundige doctorandus met een empatisch vermogen en een goed gevoel voor overleg en communicatie dan een vakkundige professor zonder enige communicatieve vaardigheid. Indien nodig moeten de teams expertise vragen uit en expertise aanbieden aan andere teams in andere ziekenhuizen. Uitwisseling van kennis en vaardigheid is cruciaal voor kwaliteit en het onderhouden van kennis. Zoals een orkest alleen goed kan presteren met een vakkundige dirigent dient de eindverantwoording te berusten op een medisch hiërarchisch model dus bij een medische specialist bekend met de medische inhoud en die tevens bekend is met medisch management. Hij kan dan op voet van gelijkheid communiceren en rapporteren aan de Raad van Bestuur en met hen direct ook aan de zorgverzekeraar. Zoals een Raad van Bestuur van een medische instelling rapporteert en verantwoording aflegt bij een Raad van Toezicht, zo zullen de leiders van deze teams verantwoording af moeten leggen aan een soort Raad van Medisch Toezicht waarvan de leden bestaan uit locale en nationale en misschien wel internationale ter zake kundige professionals. Vanuit de organisatorische hoek betrek ik hierbij ook de leden van de Raden van Bestuur van de ziekenhuizen omdat de zogenaamde Raad van Medisch Toezicht de autoriteit en mogelijkheid moet hebben disfunctionerende leden van het team aan de zijlijn te plaatsen en eventuele disfunctionerende teams omwille van de patientveiligheid en kwaliteit op te heffen.

$U$ merkt dat ik veel hogere eisen stel aan dit soort teams dan aan de vele werkgroepen en teams die reeds in vele ziekenhuizen bestaan. De door mij beschreven teams werken niet louter op basis van vrijblijvendheid en worden gecontroleerd op prestatie en kwaliteit.

Door een uniforme, perfecte, transparante registratie van patiënten, medische behandelingen, resultaten en complicaties is benchmarking met eenzelfde teams in andere ziekenhuizen mogelijk en kan kwaliteit en kwantiteit worden vergeleken nationaal en wellicht ook internationaal. Tevens maakt het de kosten vergelijkbaar en inzichtelijk.

Het op te richten spine centrum en hart-vaat centrum in Zuid-Limburg zijn een stap in de goede richting en worden door mij waar mogelijk van harte gesteund. 
Ik kom terug op de eed en citeer opnieuw:

Er wordt gezworen of beloofd:

Ik erken de grenzen van mijn mogelijkheden. Ik zal mij open en toetsbaar opstellen:

Dit is in een team alleen realiseerbaar. De team leden controleren elkaar en leggen verantwoordelijkheid af aan elkaar en aan een Raad van Medisch Toezicht. De surgical glory van de chirurg die nogal eens de besluitvorming en indicatie voor operatieve handelingen kan beïnvloeden hetgeen soms desastreuze gevolgen kan hebben, kan door de teamstructuur worden bijgesteld.

Ik citeer opnieuw:

Ik ken mijn verantwoordelijkheid voor de samenleving;

De teams moeten transparant registreren en treden eensgezind naar buiten, trots op hun resultaten .

In plaats van inspecties, de media en managers moeten de artsen zelf het initiatief nemen om verbeteringen aan te kaarten, mistanden te signaleren en de resultaten van hun medisch handelen transparant en openbaar te maken en deze te presenteren aan de media.

Met weerzin kijk ik elk jaar naar de zogenaamde onderzoeksenquêtes van Elsevier en het Algemeen Dagblad. Met onbegrip verneem ik positieve en negatieve reacties in de media en op de werkvloer in het ziekenhuis.

Van de arts wordt verwacht dat hij de patiënten behandelen zal volgens de geldende richtlijnen die gebaseerd zijn op wetenschappelijke studies.

Daarentegen wordt de kwaliteit van de Nederlandse ziekenhuizen en daarmee samenhangend het functioneren van de arts en alle andere medewerkers in het ziekenhuis beoordeeld op basis van wetenschappelijk ongevalideerde enquêtes en epidemiologisch gezien nutteloze prevalentiemetingen. Ondanks het feit dat geen enkel ziekenhuis een constante met elkaar vergelijkbare patientenpopulatie kent - denk maar eens aan variabelen als de ligging van het ziekenhuis, opnameduur, zorgzwaarte, patiëntenmix, diagnoses en ziekenhuiskarakteristieken - worden verregaande conclusies getrokken over alle ziekenhuizen in Nederland en in de media breed uitgemeten. 
Ik weet zeker dat in een ziekenhuis dat laag scoort bij deze enquêtes artsen, verpleegkundigen of andere medewerkers werken die zich met volle inzet, betrokkenheid, empathie en sympathie zich inspannen voor het lot van de patiënt. Dit horen we niet en dit zien we niet, dat heeft geen nieuwswaarde. Medisch falen en de ellende die daarbij hoort worden beoordeeld vaak zonder hoor en wederhoor. Voor de media is dit de belangrijkste bron van medisch nieuws. Hoe lang accepteert de medische specialist dit nog?

Ik ga weer terug naar de eed en ik citeer:

Ik zal zorgen voor zieken, gezondheid bevorderen en lijden verlichten. Ik stel het belang van de patiënt voorop en eerbiedig zijn opvattingen.

Bedoelt Hippocrates hier een altruïstische levenshouding van de arts? Indien dat wordt bedoeld dan gaat het misschien wel erg ver. Onbaatzuchtigheid in plaats van altruïsme zou een beter woord kunnen zijn, maar dat past niet in het huidige model van de marktwerking van de zorg. Onbaatzuchtig betekent dat alles moet worden ingezet, kosten noch moeite zouden moeten worden gespaard. De politiek trapt echter direct op de rem indien er kostenoverschrijding dreigen te ontstaan. Ik hoorde enkele maanden geleden een tweede kamer lid naar aanleiding van de presentatie van de Koran film van Wilders verklaren dat kosten noch moeite mochten worden gespaard bij het in stand houden van de vrijheid voor meningsuiting. Geen enkele politicus heb ik dit over de zorg horen zeggen

De discussie over marktwerking in de zorg gaat steeds meer over één ding: geld. Geld, dus verzakelijking in plaats van kwaliteit als criterium om concurrentie is misschien op korte termijn effectief, maar zal op langere termijn niet werken. De focus op geld en verzakelijking van de zorg heeft geleid tot een enorme bureaucratie en steeds meer onbegrip bij de werkers in de zorg die dagelijks aan het bed van de patiënt staan. Financiële managers en directies van ziekenhuizen worden gek van de rekenmodellen, regels en beperkingen die hen door de overheid worden opgelegd.

Naast de financiële regelgeving worden deartsen en verpleegkundigen en paramedici voortdurend overstelpt met nieuwe regels en verordeningen die vaak gebaseerd zijn op onderzoek en bekendmaking van medische missers en misstanden in soms een enkel ziekenhuis of erger nog soms op een enkele afdeling van een ziekenhuis. Bescherming en indekking 
tegen eventuele juridische aansprakelijkheids procedures en negatieve publicaties in de krant en op de televisie is een dagelijks onderdeel van ons werk geworden. Steeds meer werknemers in de zorg haken af omdat ze gedemotiveerd raken, steeds minder schoolverlaters kiezen voor werk in de zorg. Het personeelstekort is een van de grootste zorgen voor de toekomst van de Nederlandse gezondheidszorg die vanwege de vergrijzing alleen maar zal toenemen.

Onbaatzuchtigheid kan niet meer.We moeten denken aan ons toegekende en zelf te verdienen financiële budget hetgeen van de artsen steeds meer een koopmansgeest gaat verlangen. Onbaatzuchtig toegeven dat er een medische fout is gemaakt bij een medische behandeling kan niet ondanks de roep om transparantie. Uit eigen ervaring heb ik meegemaakt dat mijn eigen verzekeraar tegen aansprakelijkheid mij verweet dat ik openlijk een fout had toegegeven waardoor de juristen niet in staat waren een goede verdediging te voeren. Een fout mag in de medische wereld geen fout genoemd worden.

De verzakelijking en juridisering van de zorg botsen met de eed.

Voor de laatste keer ga ik terug naar de eed

De laatste regel luidt:

Ik maak geen misbruik van mijn medische kennis, ook niet onder druk. Ik zal zo het beroep van arts in ere houden."

Dit laatste is bedoeld om het misbruik van medische kennis, zoals dat tijdens de Tweede Wereldoorlog optrad, te voorkomen. Dezelfde zinsnede is echter ook van toepassing op misbruik van kennis door commerciële druk zoals die van de industrie en het marktgericht denken in de huidige zorgverlening. Stimuleert de marktwerking in de zorg niet dat de burger zich vooral als consument opstelt en juist meer zorg wil? Dit kan zorg zijn die de arts onder commerciële druk van de zorginstelling moet verlenen, en is tegen de inhoud van de eed. Anno 2008 wordt veel maakbaar geacht, je hebt recht op de beste zorg voor je eigen gezondheid, en men beschouwt het leven en lichaam als een maakbare machine. Dat beeld is absoluut onwerkelijk. Maar het gaat wél steeds meer de gezondheidszorg sturen.' De uitspraak van de arts "ik kan niets meer voor u doen" wordt niet meer geaccepteerd. Er moet een oplossing komen, de patiënt heeft daarvoor zijn premie betaald. De gezondheidszorg helemaal in een markt omvormen, kan nog wel eens 
heel duur worden. Want op de markt valt "nee, ik kan niets meer voor $u$ doen" niet te verkopen. De second en third opinion en de opinie van de beste dokter ergens op deze planeet met alle financiële consequenties van dien zijn het gevolg.

De marktwerking in de gezondheids zorg heeft echter ook voordelen. Voor het eerst in 28 jaar maak ik mee dat er in de ziekenhuizen grootschalig aandacht besteed gaat worden aan zogenaamde klantgerichtheid. Ik ben ongelukkig met het woord. We hebben geen klanten in het ziekenhuis, maar patiënten. Ziekenhuizen verkopen feitelijk niets aan patiënten, maar hebben de verzekeraars als klant. Patiënten op hun beurt zijn betalende klanten van de verzekeraars, niet van de dokters. Zij kopen geen product uit vrije wil. Ze zijn onvrijwillig ziek en vragen om zorg. Zorg die bestaat uit deskundigheid en betrokkenheid. Zorg geleverd door een team van professionals zoals ik al eerder heb genoemd. De patiënt is hierbij ook een prominent lid van het team en bereid zelf ook alles te doen wat in zijn vermogen ligt om het proces van zorg tot een goed einde te brengen.

Centraal hierin staat betrokkenheid. Betrokkenheid is geen product. Betrokkenheid ontstaat op basis van een wederzijds vertrouwen. Het klinkt wellicht wat pathetisch, maar het is toch realiteit. Een patiënt of zijn familie geven mij een onbegrensd vertrouwen als zij akkoord gaan met het feit dat ik een operatie doe aan bijvoorbeeld de schedelbasis met de kans op overlijden van 2 procent en een kans op ernstige levenslange invaliditeit van misschien 4 procent of en de kans op minder ernstige blijvende beschadigingen in een nog hoger percentage. Dit is een onbegrensd vertrouwen dat ze niemand anders en zeker niet aan politici zullen geven. Indien ik me dat vertrouwen realiseer dan vervagen woorden als klant, zorgproduct en marktwerking. Het enige dat dan telt is betrokkenheid. Dit is het unieke van ons vak als arts. Dit houdt velen met mij staande in de nogal turbulente ziekenhuiswereld om ons heen. Betrokkenheid is een van de peilers van de eed van Hippocrates. Wij, de medisch specialisten zijn de eersten die dat voortdurend moeten tonen. Wij hebben in deze een voorbeeldfunctie voor alle anderen in een ziekenhuis. Betrokkenheid verandert in onverschilligheid als een specialist of een andere medewerker zijn werk niet gerespecteerd, gewaardeerd en passend gehonoreerd ziet. Voor een patiënt die vraagt om zorg is onverschilligheid de meest frustrerende en kwetsende ervaring. Onverschilligheid mag in een zorginstelling zoals een ziekenhuis nooit voorkomen. Ik kom weer terug op mijn pleidooi voor 
de teams zoals ik ze al eerdere heb beschreven. Het gevoel bij een team te horen, het gevoel mee te werken aan een resultaat waar men trots op kan zijn, het gevoel waardering te krijgen van de patiënt, het gevoel waardering te krijgen van andere teamgenoten, van leidinggevenden en van de Raad van Bestuur zet een ziekenhuis beter op de kaart dan welke goedbedoelde cursus klantgerichtheid dan ook.

Mijn opleider in het Henry Ford ziekenhuis in Detroit: James Ausman zei het op zijn manier:

If you put the patients first, you will never have to worry about money If you put money first you will loose both.

\section{Dames en Heren,}

In het begin van mij rede pleitte ik voor het opheffen van de afdeling neurochirurgie en wellicht ook voor het opheffen van de leerstoel neurochirurgie die ik nu voor de tweede maal in mijn leven heb aanvaard.

Betekent dat het requiem voor de neurochirurgie? Indien ik dit bevestigend zal beantwoorden krijg ik de rest van mijn carrière een storm van kritiek te verduren van mij ca 100 collega's in Nederland. U hoort mij dus geen "ja" zeggen.

Maar, in de laatste 20 jaar is de neurochirurgie in een hoog tempo veranderd. Dit heeft een behoorlijke impact gehad op de functie van de neurochirurg in de kliniek.

Vanwege de enorme toename van informatie is het nog maar moeilijk om een generalist te zijn. Ook de neurochirurg is zich steeds meer gaan specialiseren.

De grote uitgebreide langdurige operaties zoals ik die als schedelbasis chirurg nog heb uitgevoerd maken steeds meer plaats voor minder uitgebreide, minder tot de verbeelding sprekende operaties. "Mininal invasive surgery" is in, en de postoperatieve kwaliteit van leven is steeds belangrijker geworden in de beslissing tot het uitvoeren van een operatie.

De functionele neurochirurgie ( ook dit is "minimal invasive surgery") heeft een enorme expansie doorgemaakt en is nu een van de meest groeiende onderdelen van de neurochirurgie.

In de oncologie en schedelbasis chirurgie zien we dat er nieuwe ontwikkelingen zijn zoals de zogenaamde "targeted molecular" therapieën: medicijnen worden ontwikkeld die bepaalde stappen in de 
formatie van tumorcellen en de bloedtoevoer naar tumorcellen kunnen blokkeren, Deze zijn reeds bekend en succesvol bij de behandeling van leukemie en sommige vormen van long, dikke darm en borstkanker en mogelijk in de toekomst ook tumoren van goedaardige en kwaadaardige oorsprong in ons vak. Het is niet onvoorstelbaar dat in de toekomst de operaties van hersentumoren niet meer nodig zullen zijn of alleen nog maar bestaan uit stereotactische implantaties van locale tumorremmers.

De verdieping in de genetische verschillen van tumoren laat ons zien dat sommige tumoren beter reageren op een medicamenteuze behandeling dan operatieve behandelingen wat van belang kan voor het neurochirurgisch aandeel in de behandeling van deze tumoren.

De ontwikkeling van de stereotactische radiotherapie en de gamma knife nemen langzaam maar zeker de plaats in van operaties van schedelbasis tumoren en hersenmetastasen.

Deze genoemde ontwikkelingen brengen het besef in het bijzonder bij onze jonge aanstaande collega neurochirurgen dat in toenemend aantal gevallen het technisch operatieve neurochirurgisch aandeel van de behandeling op de achtergrond komt te staan.

Wat kan de neurochirurg dan nog betekenen als zijn operatieve handvaardigheid niet meer nodig is dan wel alleen in beperkte mate nog nodig is? Moeten we aan de zijlijn gaan staan en wachten tot we gevraagd worden en moeten we minder neurochirurgen opleiden?

Collega Clemens Dirven stelt deze vraag ook tijdens zijn inaugurele rede na zijn aanvaarding van het hoogleraarschap neurochirurgie aan het Erasmus MC in Rotterdam in april jl. Zijn antwoord was duidelijk: onze unieke neurochirurgische vaardigheden en expertise moeten worden ingezet in de ontwikkeling van nieuwe technische vindingen en hij stimuleerde onze aankomende vakgenoten om nieuwe kennis op te doen in de laboratoria.

Ik ben het met hem eens. Echter ik wil een stap verder gaan.

We moeten ook nieuwe kennis opdoen in de kliniek. We moeten aansluiting zoeken in de diverse behandelteams en onze kennis en ervaring inbrengen ook al leidt dat niet primair tot een operatie. We moeten met onze kennis respect afdwingen en laten zien dat we meer kunnen dan opereren alleen. Omdat we teveel geconcentreerd waren op alleen onze technische handvaardigheid hebben we nieuwe ontwikkelingen gemist. 60-70\% Van de intracraniële aneurysmata worden niet meer primair door de neurochirurg behandeld. Moet dat ook het geval gaan worden bij de behandeling van bijvoorbeeld 
schedelbasistumoren?. Alleen de neurochirurg kent door ervaring het gedrag van bijvoorbeeld de vestibulaire schwannomen en meningiomen, chordomen en chondrosarcomen aan de schedelbasis, hij kent de anatomie van waaruit deze tumoren groeien, hij kent het fenomeen en verschil van een hersenstamverplaatsing ten gevolge van de ene of andere schedelbasis tumor. Hij kent de prognose. Staat hij dan met deze kennis en ervaring aan de zijlijn omdat er niet meer geopereerd wordt? Mogen we bij de behandeling van patiënten met de gamma knife of andere stereotactische radiotherapeutische behandelingen alleen maar het schroefje van het frame aandraaien of doen we meer? Aan ons de keus. De grenzen van de specialismen vervagen, we moeten specialiseren en aansluiting zoeken bij andere specialismen en wij moeten hergroeperen. Het woord "change" is de laatste paar dagen vaak gehoord en gezien in het kader van de Obamania. Ook de neu rochirurgen moeten veranderen. Er zal niets veranderen, als we zelf niet veranderen.

\section{Wat doen we en gaan we doen in Limburg?}

De neurochirurgen van het Neurochirurgisch Centrum Limburg hebben een zorgtaak voor wat betreft basale neurochirurgie in Limburg.

Besprekingen met betrekking tot uitbreiding van het neurochirurgische pakket in het Vie Curie ziekenhuis in Venlo zijn in volle gang. In de ziekenhuizen in Roermond en Weert zullen wij onze neurochirurgische expertise blijven aanbieden en indien gewenst versterken. De afdeling neurochirurgie van het Atrium ziekenhuis te Heerlen is vanouds de bakermat van de neurochirurgie in Zuid Limburg. Samen met de afdeling neurochirurgie van het Maastrichts Universitair Medisch Centrum vormt dit het Neurochirurgische Centrum Limburg. Tussen beide afdelingen bestaat op voet van gelijkheid een differentiatie van behandelingen. Ik wil streven naar meer communicatie over en weer tussen beide afdelingen ter optimalisering van de efficiëntie en kwaliteit. Er mag geen sprake zijn van een "living apart, together" situatie. De business plannen die voor beide afdelingen in voorbereiding zijn zullen als een puzzel in elkaar gaan vallen.

Zeer recent heb ik besprekingen gehad met het hoofd van de afdeling neurochirurgie van de Universiteit van Aken. We hebben de intentie tot een nauwe samenwerking uitgesproken en dit wordt in 2009 verder uitgewerkt.

Met het epilepsie centrum Kempenhaeghe is gisteren een overeenkomst getekend dat de epilepsie chirurgie in Maastricht in samenwerking met Kempenhaeghe gecontinueerd kan worden voor de volgende twee jaar. 
De wetenschappelijke activiteiten blijven geconcentreerd in een viertal projecten.

De functionele neurochirurgie met de volgende onderdelen.

- Deep Brain Stimulation (DBS) bij bewegingsstoornissen en psychiatrische aandoeningen

- Epilepsie chirurgie

- Behandeling van pijn en spasticiteit

De combinatie van basaal wetenschappelijk onderzoek en de klinische toepassing in het academische ziekenhuis maakt de functionele neurochirurgie in Maastricht uniek nationaal en internationaal.

De recente oprichting van MIND, het Maastricht Institute for Neuromodulative Development, zal de herkenbaarheid van de functionele neurochirurgie in binnen-, en buitenland doen toenemen. Aan dit deelgebied is een leerstoel verbonden met de benoeming van professor Veerle Visser-van de Walle en er is een grote stroom van publicaties. Momenteel lopen er zeven promotietrajecten rechtstreeks verbonden aan de afdeling neurochirurgie, en vijf samen met andere centra of afdelingen (zoals met epilepsiecentrum Kempenhaeghe, Technische Universiteit Eindhoven, afdeling neurologie van het Leidse UMC, de afdelingen anesthesie en de afdeling neuropsychologie van het Academisch ziekenhuis Maastricht.) Bovendien zijn twee Veni aanvragen gehonoreerd. Een aan onze assistent in opleiding Yasin Temel voor het onderzoek naar DBS bij depressie en aan onze assistent in opleiding Marc Damen voor onderzoek naar de mechanismen van neuropathische pijn na lumbale hernia operaties.

De MIND maakt voor wat betreft het onderzoek een deel uit van de School for Mental Health and Neurosciences onder leiding van professor Harry Steinbusch.

Een tweede project is de spinale neurochirurgie

De spinale neurochirurgie sluit aan bij 2 reeds bestaande landelijk bekende expertises van de afdeling neurochirurgie in Maastricht; namelijk de functionele neurochirurgie en operatieve behandeling de thoracale hernia die door collega Erwin Conips zo fantastisch in Maastricht op de kaart is gezet.

Tevens sluit het aan bij het voornemen tot oprichting van een multidisciplinair Spine Centrum. Collega Henk van Santbrink participeert 
namens de neurochirurgie hierin samen met het Pijn Kennis Centrum, en de afdelingen Orthopaedie van het Academisch ziekenhuis en het Atrium ziekenhuis in Heerlen.

In het Spine Centrum wordt gestreefd naar internationale samenwerking tav onderzoek, de eerste contacten zijn hiervoor met de Cleveland Clinics gelegd

De reeds bestaande samenwerking tussen de afd. orthopaedie en neurochirurgie heeft reeds tot subsidie bijdragen geleid voor de aanstelling van een spine fellow en $4^{\mathrm{e}}$ geldstromen.

Het derde project is de kinderneurochirurgie, met met name aandacht voor de zeldzame of complexe midline aandoeningen. Besprekingen dienaangaande moeten nog worden gevoerd. Dit project stelt specifieke eisen aan de infrastructuur van het academisch ziekenhuis en aan de deskundigheid van de hulpverleners op het gebied van de kinderneurologie, neurofysiologie ,anesthesiologie en de psychosociale hulpverlening.

Dit is in het academisch ziekenhuis van Maastricht aanwezig en kan als een topreferente functie worden uitgebouwd door de collegas Cornips en Ter Laak middels promotieonderzoeken, nationale en euroregionale klinische en wetenschappelijke profilering en operatieve technologische innovaties. Aangezien het om een relatief gering aantal patiënten zal samenwerking worden gezocht met de universiteiten van Aken en Luik..

Plexus brachialis chirurgie

De plexus brachialis chirurgie blijft gepositioneerd in het Atrium Medisch Centrum in Heerlen. Er is gesproken over uitbreiding van de regio van verwijzing met de neurochirurgen in Aken die welwillend staan tegenover het plan de patiënten met een plexus laesie te verwijzen naar Heerlen. Collega Ferrie van Nie is al enige jaren de voortrekker. Om de twee jaar wordt een internationaal symposium in Heerlen door de plexuswerkgroep georganiseerd. 
Tot slot wil ik mijn dank uitspreken aan velen die direct of indirect hebben bijgedragen aan het feit dat ik hier sta.

Aan mijn ouders, die deze dag niet meer hebben mogen mee maken omdat zij beide op hoge leeftijd overleden zijn, aan mijn patiënten die mij hun vertrouwen hebben gegeven.

Aan het college van Bestuur van de Universiteit Maastricht en aan de Raad van Bestuur van het Maastricht Universitair Medisch Centrum voor het vertrouwen in mij gesteld.

Grote dank ben ik verschuldigd aan drie Utrechtse neurochirurgen van het eerste uur. Zij hebben op mij de meeste indruk gemaakt.

Professor Kees Tulleken, hier aanwezig. Ik was jouw eerste assistent die je aannam nadat je in Utrecht hoogleraar was geworden. Ik heb het je vaker gezegd; ik heb meer van je geleerd dan de neurochirurgie alleen. Voor mij was je de ideale opleider. Jouw grenzeloos optimisme contrasteerde nog wel eens met mijn Calvinistische somberheid, later heb ik hierdoor, naar mijn smaak, goede mix gevonden.

Tom Dokkum, ook hier aanwezig. Als het niets zou worden in de neurochirurgie, dan kon ik altijd jouw auto nog gaan wassen, dat vertrouwde je mij toe. Beste Tom, een grotere uitdaging heb ik niet gekend.

Professor Kees van Veelen. Hij belde mij gisteravond dat hij hier niet aanwezig kon zijn door onvoorziene omstandigheden. Toch wil ik niet onvermeld laten dat zijn professionele gewetensvolle nauwkeurigheid voor mij altijd een voorbeeld is geweest.

Mijn dank gaat uit naar professor Berend Hillen, anatoom en mijn promotor. Ik was je eerste promovendus. Het was een plezier om bij jou te mogen promoveren. Samen kijken we nog wel eens terug naar die tijd dat ik temidden van de warmte van jou gezin mijn manuscript met jou besprak. Telkens weer vol potloodstrepen kreeg ik het terug. Schrijf toch op wat je bedoeld, was altijd weer jouw gevleugelde uitspraak. De tekst moest altijd korter. Berend, jij bent in staat om ook deze rede in twee regels samen te vatten.

Mijn dank gaat uit naar mijn toenmalige collega's van het neurochirurgisch centrum Nijmegen. Als betrekkelijke jonge hoogleraar kwam 
ik in hun midden, het was een moeilijke tijd, zij hebben mij gesteund en ik heb er veel geleerd. Een lid van de Raad van Bestuur van het Radboud ziekenhuis heeft mij indertijd wel eens beschreven als een jonge hond. Hij had gelijk: jonge honden hebben wegloop neigingen.

De maatschap neurochirurgie van het St. Elisabeth ziekenhuis te Tilburg. In het begin van deze rede heb ik over een ideaal team gesproken. Wij waren zo'n team, hetgeen moge blijken uit het feit dat we de grootste afdeling neurochirurgie van Nederland met inbegrip van 16 ziekenhuizen in Brabant zonder ruzie, met een collegiaal vertrouwen en een heerlijke lach op top nivo in de lucht wisten te houden. Waarom ben ik dan weggegaan? Een professor weet veel, maar begrijpt niet alles. Ik laat jullie nog niet los en hoop nog lang een lid van het Gamma Knife team te mogen blijven.

Mijn dank gaat uit naar Professor Emile Beuls, die ik heb opgevolgd in Maastricht. Emile, je bent in Maastricht met niets begonnen, ik heb een goed lopende afdeling met een prestigieus wetenschappelijk programma van je overgenomen. We hebben samen 5 maal een cursus schedelbasischirurgie met een internationale faculty in Maastricht/ Diepenbeek georganiseerd. Onze samenwerking is de basis van mijn aanstelling hier.

Ik dank Henk van Santbrink. Jij had de leiding in de interim periode tussen professor Beuls en mij. Toen ik nog niet in Maastricht was betrok je mij al bij te nemen beslissingen en help je me nog steeds. Dat noem ik klasse.

De Maastrichtse collega's van de afdeling neurochirurgie. Mijn dank voor jullie vertrouwen en de privileges die ik van jullie krijg. Jullie werken erg hard met fantastische resultaten op neurochirurgisch en wetenschappelijk gebied. Het is voor mij een eer met jullie mee te mogen doen en leiding te mogen geven.

Mijn assistenten van de afdeling neurochirurgie. Hetzelfde geldt voor jullie. Ik heb respect voor jullie. Harde werken in de kliniek, gegijzeld door het werktijdenbesluit. Daarnaast wetenschap op internationaal nivo en een promotie en dan voor sommigen ook nog een jong gezin. 
Mijn dank gaat ook uit naar het secretariaat van de neurochirurgie. Jullie betrokkenheid en inzet bij mijn werk en jullie geduld om mij weer eens de weg te wijzen of uit te leggen hoe het in Maastricht gaat waardeer ik enorm.

Dank ben ik eveneens verschuldigd aan de medewerkers van het cluster bureau van onze Resultaat Verantwoordelijke Eenheid die mijn managements taken op zeer plezierige wijze ondersteunen.

De verpleegkundigen en andere medewerkers van de afdeling neurochirurgie en de medewerkers op de operatiekamers ben ik veel dank verschuldigd. Dit jaar hebben we een forse productie stijging gehad en jullie hebben dat mogelijk gemaakt. Onze operatie kamers hebben we voor $130 \%$ bezet, wat alleen maar mogelijk was door de inzet van de anesthesiologen en operatie personeel en dat terwijl er een tekort aan medewerkers is en er dus vacatures zijn.

Last but not least, mijn alles wat ik heb, mijn gezin. Emma, Chris, Joshua en Emmelientje.

Een gezin lijkt zo normaal

Maar het is een droom

Ik kan absoluut niet zonder

Want mijn gezin is een wonder.

Ik dank u allen voor uw komst en uw aandacht,

Ik heb gezegd. 
